Науковий вісник Ужгородського університету

Серія Біологія, Випуск 45 (2018): 20-32

(C) Загороднюк I., Баркасі 3. 2018

DOI: $10.24144 / 1998-6475.2018 .45 .20-32$

\title{
ССАВЦІ КАРПАТ У ЧЕРВОНІЙ КНИЗІ УКРАЇНИ
}

\author{
Загороднюк І., Баркасі 3.
}

Mammals of the Carpathians in the Red Data Book of Ukraine. - I. Zagorodniuk, Z. Barkaszi. -The composition of the mammal fauna of the Ukrainian Carpathians is analysed, which includes 77 species of 19 families. Compared to the previous checklist of Carpathian mammals (1997), 5 species that occur only in adjacent plains or have not been recorded in the region for a long time were excluded and 4 new alien and sibling species were added to the current checklist. According to the latest (third) edition of the Red Data Book of Ukraine (2009), 39 mammal species from the Carpathians obtained protected status. Compared to the previous edition, in which 20 mammal species were listed, the number of rare species in the new edition increased twice. Most species belong to bats (24 species), carnivores (7), and rodents (5). Among them, the distribution of 5 species in Ukraine as of 2009 was restricted to the Carpathian region: Spalax graecus, Terricola tatricus, Chionomys nivalis, Sorex alpinus, and Ursus arctos. Analysis of changes in the content of the new list of protected species and of their statuses shows an essential deterioration of population state of many species. According to the results of this review, two species obtained the status "extinct" (Miniopterus schreibersii and Eliomys quercinus). The status of a number of species was risen and six species were entitled by the status "disappearing" (Rhinolophus ferrumequinum, Myotis emarginatus, Myotis dasycneme, Barbastella barbastellus, Chionomys nivalis, and Ursus arctos) and two species became "critically endangered" (Spalax graecus, Mustela lutreola, and Bison bonasus). At the same time, the status of 4 species was soften (Myotis daubentonii, Plecotus austriacus, Eptesicus nilssonii, and Felis silvestris), while 8 species are beyond the risk of disappearance (Plecotus austriacus, Nyctalus noctula, Pipistrellus pipistrellus, Pipistrellus pygmaeus, Pipistrellus kuhlii, Eptesicus serotinus, Arvicola scherman, and Mustela putorius). The issues of coordination of conservation statuses of different mammal species were considered in detail since IUCN criteria have not been used in Ukraine, as well as the shortcomings in approaches to the creation of red lists. The effectiveness of maintaining open access and constantly updated databases for the assessment of conservation statuses of species, similarly to the IUCN database, is highlighted.

Key words: mammals, rare and endangered species, Red Data Book of Ukraine, Carpathians.

Address: National Museum of Natural History, NAS of Ukraine, 15 Bohdan Khmelnytsky st., Kyiv, 01030 Ukraine; e-mail: igor.zagorodniuk@gmail.com

Ссавці Карпат у Червоній книзі України. - I. Загороднюк, З. Баркасі. - Проаналізовано обсяг теріофауни Українських Карпат, яка включає 77 видів із 19 родин. Попередній контрольний перелік видів ссавців Східних Kарпат (1997 р.) переглянуто у бік його скорочення на 5 видів, які поширені лише у передгір'ях або давно не реєструються у регіоні, а також у бік доповнення його 4 новими видами з числа адвентивних видів та видівдвійників. Згідно з ІІІ виданням Червоної книги Украӥни (2009), 39 видів ссавців, поширених у Карпатах, отримали охоронний статус. Новий «червоний» перелік 2009 року збільшив частку раритетних видів ссавців рівно удвічі (було 20 видів), і його основу складають кажани (24 види), хижі (7 видів) і гризуни (5 видів). У переліку $є$ 5 видів, поширення яких в Украйні станом на 2009 р. обмежене лише Карпатами - Spalax graecus, Terricola tatricus, Chionomys nivalis, Sorex alpinus ma Ursus arctos. Аналіз змін переліку «червонокнижних» видів та змін їхніх категорій засвідчуе погіршення стану популяцій багатьох із них. За підсумками изого огляду, два види визнано зниклими (Miniopterus schreibersii, Eliomys quercinus). Для низки видів категорії посилено, та 6 видів карпатських ссавиів отримали категорію «зникаючий» (Rhinolophus ferrumequinum, Myotis emarginatus, Myotis dasycneme, Barbastella barbastellus, Chionomys nivalis, Ursus arctos) плюс 2 - «критично загрожений» (Spalax graecus, Mustela lutreola, Bison bonasus). Для 4 видів категорія пом'якшена (Myotis daubentonii, Plecotus auritus, Eptesicus nilssonii, Felis silvestris), щзе 8 видів виходять за межі ризиків зникнення (Plecotus austriacus, Nyctalus noctula, Pipistrellus pipistrellus, Pipistrellus pygmaeus, Pipistrellus kuhlii, Eptesicus serotinus, Arvicola scherman, Mustela putorius). Розглянуто проблему узгодження охоронних статусів видів ссавців (критерії МСОП в Україні не діють) та недоліки у підходах до формування червоних переліків. Відмічено ефективність ведення відкритих і поновлюваних баз даних щуодо очінок статусу видів за прикладом бази даних МСОП.

Ключові слова: ссавці, рідкісні та зникаючі види, Червона книга Украӥни, Карпати.

Адреса: Національний науково-природничий музей НАН Украӥни; вул. Богдана Хмельницького 15, м. Київ, 01030 Україна; e-mail: igor.zagorodniuk@gmail.com 


\section{Вступ}

Ідея формування «червоних» переліків в Україні не нова. Заборони та ліміти на використання природних ресурсів існують в Україні з давніх часів, проте набули законодавчої підтримки лише 7 лютого 2002 р., коли було прийнято Закон України «Про Червону книгу України» (Zakon ... 2002). Відповідно до цього Закону, «Кабінет Міністрів України забезпечує офіційне видання та розповсюдження Червоної книги України не рідше одного разу на 10 років» (ст. 12). Враховуючи, що перше видання побачило світ 1980 року, друге - 1994 р., третє 2009 p. (Chervona ... 1980, 1994, 2009), маємо явне перевищення 10-річного циклу (14-15 років), і можна розуміти, що збереження статусу кожного 3 видань як ключового природоохоронного огляду перевищує передбачений законом термін. Цей час, згідно із Законом, відведено для «регулювання суспільних відносин у сфері охорони, використання та відтворення ... видів тваринного і рослинного світу, занесених до «Червоної книги України», з метою попередження зникнення таких видів...» (ст. 2), а також «для розроблення та реалізації програм (планів дій), спрямованих на [їхню] охорону та відтворення...» (ст. 3).

Очевидно, що найбільшою мірою від всеохоплюючого антропогенного чинника потерпають хребетні тварини, а поміж них - ссавці, які характеризуються низкою особливостей, що визначають їхню високу частку у червоних переліках, і низкою біологічних особливостей, що роблять їх надзвичайно уразливими через їхню спорідненість 3 людиною та їхні претензії на ті самі природні ресурси, якими хоче володіти людина (Zagorodniuk 2000). Годі казати про peсурсне значення самих ссавців, смак м'яса i цінність трофеїв з яких не дають спокою півмільйону мисливців і принаймні втричі більшій за обсягом (не рахуючи рибалок) когорті браконьєрів. Все це різноманіття, дякуючи ЧКУ, знаходиться під пильним оком природоохоронців і у більшості своїх проявів забезпечене охороною держави, а отже і всіх державних установ та законослухняних громадян.

Отже, метою цієї праці став аналіз третього, поточного «червоного» переліку тварин, що охороняються згідно з волевиявленням наших громадян та рішень Національної комісії з Червоної книги України і Міністерства охорони навколишнього природного середовища у тій частині, яка стосується ссавців, тобто гомойотермних амніотичних тетрапод з ознаками розсудливої діяльності, живородінням і турботою про нащадків. Все це різноманіття охоплює гризунів, землерийок, кажанів, хижих і ратичних, разом 68 видів 9-ти рядів за прийнятою у «Червоній книзі України» класифікацією. Статтю написано 2009 року і поновлено у 2012, 2015 та 2019 роках, завдяки чому рукопис пройшов непросту еволюцію від вражень про зміст і якість даних у III виданні ЧКУ до пропозицій щодо IV видання.

\section{Результати}

Обсяг східнокарпатської теріофауни. До «Червоної книги України» 2009 року внесено значну кількість ссавців карпатського регіону, загалом близько 40 видів з 68 включених до ЧКУ, тобто понад половини наявного у «Червоній книзі» різноманіття теріофауни України. Важливо відмітити, що «червоний» перелік ссавців, поширених в Карпатах, зріс порівняно 3 попереднім на $\sim 50 \%$ (було 20 видів: Zagorodniuk et al. 1997), що вносить суттєві корективи у регіональні «червоні списки» (Witkowski et al. 2003; Mateleshko, Potish 2011; Stetsula 2015).

Перед тим, як розглянути особливості регіонального переліку власне раритетів і так званих «названих раритетів» (за: Zagorodniuk 2008а), необхідно уточнити обсяг «червоного» сегменту теріофауни відносно меж регіону. Це особливо важливо з огляду на те, що на прилеглих до Карпат рівнинах мешкає чимало «червонокнижних» видів, таких як хом'як, сліпаки, ховрахи, тхір степовий тощо, і мережею міжгірних долин такі види можуть проникати углиб гір і формально відноситися до гірських фауністичних угруповань (Kyseliuk 1993; Kolyushev 1957; Sokur 1951; Tatarinov 1955). За основу для аналізу обсягу теріофауни Українських Карпат прийнято огляд «Таксономія ссавців східнокарпатського регіону» (Zagorodniuk et al. 1997), проте у поточну версію цього огляду внесено деякі зміни.

Зокрема, з переліку карпатських видів виключено 5 видів степових ссавців, що проникають лише у найнижчі ділянки передгір'їв: тхір степовий (Mustela eversmanni), хом'як звичайний (Cricetus cricetus), обидва види ховрахів (Spermophilus citellus, S. odessanus), білозубка білочерева (Crocidura leucodon). До переліку додано єнота уссурійського (Nyctereutes procyonoides) і два види нетопирів: один 3 них (Pipistrellus kuhlii) знаходиться у стані розселення на північ і наразі охопив своїм ареалом усі Карпати (Sachanowicz et al. 2006), а другий (P.pygmaeus) є видом-двійником «звичайного» нетопира, i до 2000 р. не був відомий в Україні 
(Zagorodniuk, Nehoda 2001), проте тепер визнаний широко поширеним видом (Zagorodniuk 2018). Також до переліку фауни додано жолудницю Eliomys quercinus, виявленого у давніх зборах із Рахівщини (Dykyy, Zagorodniuk 2005). За останні роки так і не з'явилося нових повідомлень про знахідки в Українських Карпатах довгокрила (Miniopterus schreibersii), останню колонію якого виявлено 1990 p. (Pokynchereda 1991). Імовірно, два останні види надалі можуть бути вилучені зі списку фауни. У той же час, в мисливських господарствах Прикарпаття утримують лань (Dama dama) і муфлона (Ovis musimon), які, імовірно, можуть бути додані у контрольний перелік видів. Окрім того, один вид кажанів наводився у першій версії огляду (і наводиться в ЧКУ) під чужою назвою: українські «Myotis blythii» насправді є M. oxygnathus. Також зазначимо, що карпатські стада зубрів (Bison bonasus) отримали в новому виданні ЧКУ статус «зниклих у природі», що має бути стверджено чи спростовано подальшою практикою.

Отже, у переліку східнокарпатської теріофауни маємо такі зміни:

1) із вихідного списку з 78 видів вилучено п'ять, лише умовно належних до карпатської фауни; 2) додано 4 види, раніше не відомі для фауни регіону; 3) ймовірно, зі списку мають бути виключені два види, які за останні 2-4 десятиліття не зареєстровані в Україні (поки залишені); 4) ймовірно, до фауни мають бути включені два чужорідних види копитних, яких утримають у напіввільних умовах (тут не включені). Виходячи 3 цього, маємо у переліку майже ту саму кількість видів $(78-5+4-2 ?+$ $+2 ?=77)$, що і в попередньому.
3 цього видно, що обсяг систематичного списку карпатської теріофауни залишається відносно сталим, хоча постійно відбуваються його зміни, у т. ч. внаслідок появи (інвазії та інтродукції) одних видів та зникнення (вимирання, скорочення ареалів) інших видів. Ці зміни загалом є ознакою негативного розвитку фауністичних комплексів і критичного стану карпатських екосистем, проте ступінь їх змін $є$ нижчим, порівняно 3 іншими регіонами України (Zagorodniuk 2014; Barkaszi 2018).

Поява у «червоних» переліках нових видів, колись звичайних (докладніше далі), а також відсутність будь-якої сучасної інформації про стан популяцій частини давно визнаних рідкісними видів означають лише одне: подальший регрес фауністичних комплексів карпатських ссавців загалом та їх найбільш раритетного сегменту - видів, що зустрічаються в Україні виключно в межах Карпат.

Карпатський сегмент теріофауни в ЧкУ. За оцінками, наведеними в першій ревізії теріофауни Українських Карпат, в ЧКУ було 20 видів 378 наявних в регіоні (Zagorodniuk et al. 1997), тобто 26\% теріофауни регіону. Наразі загальна оцінка видового багатства $\epsilon$ такою самою (78 видів), проте на сторінках ЧКУ опинилося вже 39 «карпатських» видів (табл. 1). До i без того немалого переліку «червонокнижних» видів ссавців Карпат додалося 18 (!) нових. Отже, частка раритетного ядра теріофауни Карпат тепер складає близько 50\%, тобто екосистема Карпат фактично втратила «контрольний пакет акцій», які забезпечують існування i сталий розвиток фауни регіону та збереження іiі видового багатства та різноманіття.

Таблиця 1. Кількість видів ссавців, внесених до третього видання Червоної книги України

Table 1. The number of mammal species listed in the third edition of the Red Data Book of Ukraine

\begin{tabular}{|c|c|c|c|c|c|c|}
\hline \multicolumn{2}{|l|}{ Ряд ссавців* } & \multicolumn{2}{|c|}{ Україна загалом } & \multicolumn{3}{|c|}{ Карпатський регіон } \\
\hline Уніфікована назва & Давніша описова назва & $\begin{array}{c}\Sigma \text { видів в } \\
\text { ЧКУ }\end{array}$ & $\begin{array}{l}\text { у т. ч. } \\
\text { нових }\end{array}$ & $\begin{array}{c}\Sigma \text { видів в } \\
\text { ЧКУ }\end{array}$ & $\begin{array}{l}\text { у т. ч. } \\
\text { нових }\end{array}$ & $\begin{array}{l}\text { унікальних } \\
\text { для Карпат }\end{array}$ \\
\hline Leporiformes & Lagomorpha - зайцеподібні & 1 & 0 & 0 & 0 & 0 \\
\hline Muriformes & Rodentia - гризуни & 20 & 10 & 5 & 2 & 3 \\
\hline Soriciformes & Insectivora — комахоїдні & 5 & 1 & 2 & 0 & 1 \\
\hline Vespertilioniformes & Chiroptera - кажани & 26 & 14 & 24 & 14 & 0 \\
\hline Caniformes & Carnivora - хижі & 11 & 3 & 7 & 2 & 1 \\
\hline Delphiniformes & Cetacea - дельфіни & 3 & 0 & 0 & 0 & 0 \\
\hline Cerviformes & Artiodactyla - ратичні & 1 & 0 & 1 & 0 & 0 \\
\hline Equiformes & Perissodactyla - конеподібні & 1 & 1 & 0 & 0 & 0 \\
\hline Разом & & 68 & 29 & 39 & 18 & 5 \\
\hline
\end{tabular}

* Порядок наведення рядів відповідає сучасним класифікаціям (Wilson, Reeder 2005). У розрахунки включено види, які вважають зниклими або щодо яких нові дані відсутні (довгокрил, жолудниця, зубр). 
Найбільш представницькою групою в останньому «червоному» переліку (Perelik ... 2009) є кажани: маємо 24 їхніх види із 39 видів «карпатських» ссавців, включених до переліку. Друге місце посідають хижі (7 видів), третє гризуни (5). Інші ряди представлені 1-2 видами (комахоїдні, ратичні). Аналогічними є обсяги доповнень до «червоного» переліку: у ЧКУ-4 додано 14 видів кажанів і по два види хижих і гризунів (табл. 1). Рейтингові позиції окремих родин у новому «червоному» переліку є подібними до позицій рядів (табл. 2). Найбільш уразливими серед родин $є$ родини лиликових (22 види, у т. ч. 14 нових для «червоного» переліку) та мустелових (4 види, у т. ч. один новий вид у переліку 2009 р.).

Важливо зазначити, що у «червоному» переліку карпатських видів ссавців є 5 видів, поширення яких в Україні обмежене лише Карпатами, у тому числі три види гризунів та один вид хижих (Korobchenko, Zagorodniuk 2009; Chişamera et al. 2014; Barkaszi 2016). Цими видами $є$ сліпак буковинський (Spalax graecus), нориця татринська (Terricola tatricus), снігурка альпійська (Chionomys nivalis), мідиця альпійська (Sorex alpinus) та ведмідь бурий (Ursus arctos), ареал якого в Україні тепер обмежений лише Карпатами. Всі ці види є найбільш цінним сегментом карпатської теріофауни, оскільки їхнє збереження в Україні залежить виключно від стану саме карпатських популяцій.

Окрім того, необхідно пам'ятати, що Карпати є регіоном поширення найбільш стійких в Україні популяцій низки інших видів, внесених до ЧКУ. Такими, зокрема, $є$ рясоніжка мала (Neomys anomalus), а також - до певної міри нічниця довговуха (Myotis bechsteinii), широковух європейський (Barbastella barbastellus), пергач північний (Eptesicus nilssonii), рись європейська (Lynx lynx), зубр (Bison bonasus) та ін.

Таблиця 2. Таксономічне багатство родин ссавців Карпатського регіону України (за Zagorodniuk et al. 1997 з уточненнями) і розподіл кількості «червонокнижних» видів за родинами (ранжування за кількість видів в ЧКУ і далі за загальною кількістю видів та назвами родин)

Table 2. Taxonomic richness of mammalian families in the region of the Ukrainian Carpathians (after Zagorodniuk et al. 1997 with additions) and the distribution of the number of "red" species by families (ranking by the number of species in RDBU and by the total number of species in families)

\begin{tabular}{|c|c|c|c|c|c|}
\hline \multicolumn{2}{|c|}{ Систематична група } & \multirow{2}{*}{$\begin{array}{c}\text { Видів } \\
\text { загалом }\end{array}$} & \multicolumn{3}{|c|}{ Кількість видів в ЧКУ } \\
\hline Ряд (за ЧКУ) & Родина * & & ycix & нових & унікальних \\
\hline Chiroptera & Vespertilionidae — лиликові (було 20) & 22 & 22 & 14 & 0 \\
\hline Carnivora & Mustelidae - мустелові (було 10) & 9 & 4 & 1 & 0 \\
\hline Rodentia & Arvicolidae - щурові & 9 & 2 & 1 & 2 \\
\hline Insectivora & Soricidae — мідицеві (було 7) & 6 & 2 & 0 & 1 \\
\hline Carnivora & Felidae - котові & 2 & 2 & 0 & 0 \\
\hline Chiroptera & Rhinolophidae - підковикові & 2 & 2 & 0 & 0 \\
\hline Rodentia & Gliridae - вовчкові (було 3) & 4 & 1 & 0 & 0 \\
\hline Artiodactyla & Bovidae - бикові & 1 & 1 & 0 & 0 \\
\hline Rodentia & Sminthidae — мишівкові & 1 & 1 & 1 & 0 \\
\hline Rodentia & Spalacidae - сліпакові & 1 & 1 & 0 & 1 \\
\hline Carnivora & Ursidae - ведмедеві & 1 & 1 & 1 & 1 \\
\hline Rodentia & Muridae — мишеві & 8 & 0 & 0 & 0 \\
\hline Carnivora & Canidae - псові (було 2) & 3 & 0 & 0 & 0 \\
\hline Artiodactyla & Cervidae - оленеві & 3 & 0 & 0 & 0 \\
\hline Insectivora & Erinaceidae - їжакові & 1 & 0 & 0 & 0 \\
\hline Rodentia & Leporidae - зайцеві & 1 & 0 & 0 & 0 \\
\hline Rodentia & Sciuridae - вивіркові (було 3) & 1 & 0 & 0 & 0 \\
\hline Artiodactyla & Suidae - свиневі & 1 & 0 & 0 & 0 \\
\hline Insectivora & Talpidae — кротові & 1 & 0 & 0 & 0 \\
\hline Rodentia & Cricetidae - хом'якові (було 1) & 0 & 0 & 0 & 0 \\
\hline Разом & 19 родин & 77 & 39 & 18 & 5 \\
\hline
\end{tabular}

Примітка. * В дужках вказано кількість видів за Zagorodniuk et al. 1997, якщо ця кількість була іншою. 
У той самий час два види, що характерні для фауни Карпат, - нориця гірська (Arvicola scherman) та борсук європейський (Meles me$l e s)$ - виключені з нового видання ЧКУ як такі, стан популяцій яких тепер, як можна зрозуміти, вважають задовільним або принаймні кращим за стан популяцій інших видів, проте пояснень скасування охоронного статусу цих двох видів знайти в Червоній книзі не вдалося.

Проте, чи все так добре?

Тенденції змін стану популяцій. Якщо розглядати «Червону книгу» як джерело інформації про наявність видів, які потребують уваги людей, то поповнення переліків «червонокнижних» видів можна розглядати як ознаку покращення наших знань про фауну та підвищення природоохоронної свідомості людей. Проте, існують не тільки переліки видів, але й категоpiї, які за критеріями Міжнародного союзу охорони природи (МСОП) відображають не так ступінь нашої екологічної свідомості чи рівня турботи про фауну, як оцінку поточного стану популяцій та ризик вимирання виду взагалі або на певній території (Parnikoza et al. 2005).

Отже, важливою інформацією про зміни стану популяцій $\epsilon$ порівняння категорій видів у попередньому і поточному виданнях ЧКУ. Такі порівняння представлено у таблиці 3 , в якій остання колонка відображає оцінку і напрямок змін стану популяцій видів за роки, що розділяють два видання ЧКУ, тобто зміни за 15 років. У частині випадків ці зміни можуть стосуватися не стану популяцій, а наших знань про цей стан, проте у кожному разі такі порівняння $\epsilon$ показовими. При цьому варто зауважити, що автори відповідних нарисів до ЧКУ, у тім числі й автори цих рядків, не мали стосунку до формування переліку «червонокнижних» видів та їхніх категорій. Можливо, був задум отримати незалежні від вже присуджених категорій оцінки стану популяцій від авторів нарисів.

Порівняння категорій видів показують наступне:

1) абсолютна більшість видів у переліку характеризується помітним погіршенням їхнього статусу, а, отже, і збільшенням ризиків їхнього зникнення; тільки у 7 випадках із 17-ти мова йде про збереження «старих» категорій або приблизну рівність старих і нових категорій; більшість нових видів (а таких 18!) отримали нейтральну категорію «вразливий», у частині випадків (9) - «рідкісний», у трьох випадках — «неоцінений» (нетопир лісовий Pipistrellus nathusii, нетопир пігмей Pipistrellus pygmaeus, тхір хатній Mustela putorius);
2) один вид (кіт лісовий Felis silvestris) є таким, що покращив стан своєї популяції (категорію змінено зі «зникаючий» на «рідкісний»); ще один вид (нетопир білосмугий Pipistrellus kuhlii) покращив стан популяції і переведений 3 категорії «рідкісний» у «не загрожений». Сталу тенденцію до росту популяції демонструють кілька інших кажанів, зокрема й підковик малий, Rhinolophus hipposideros (попри очевидну залежність від охорони, але тепер такої групи категорій немає). Відображена у цих категоріях тенденція до покращення популяцій зазначених видів ссавців тепер має стати загальною відрадою усіх, проте достеменно це можна говорити лише про Pipistrellus kuhlii, який невідомо за якими критеріями був віднесений до переліку «червонокнижних» видів ${ }^{1}$. Зміна в ЧКУ категоpiï Chionomys nivalis з «рідкісного» на «вразливий» $є$ важливим фактом, проте мотиви такої оцінки нам не відомі, як і спеціальні дослідження цього виду від часу підготовки попереднього видання ЧКУ;

3) три види (довгокрил Miniopterus schreibersii, жолудниця Eliomys quercinus та зубр Bison bonasus) визнані «зниклими» або «зниклими у природі»; це факт $є$ застереженням, проте важливо зауважити, що жодного спеціального дослідження чи публікації щодо пошуку колоній чи системного обстеження потенційних місцезнаходжень довгокрила, окрім давньої публікації (Pokynchereda 1991) про знахідки довгокрила «звичайного» у Карпатах не з'явилося; окрім того, на 16 Теріошколі (2009 р.: Parkhomenko, Zagorodniuk 2012), де активно обговорювали проект III видання ЧКУ, було дві доповіді про стан популяцій зубра у Карпатах, в яких мови про їхнє зникнення не було (тут його включено до категорії «близький до зникнення»: табл. 5); Щодо статусу жолудниці Eliomys quercinus (paніше категорія «невизначений») очевидною $€$ відсутність виду у сучасній фауні, тому не зрозуміло, чому цей вид отримав категорію «зникаючий», якщо інші види 3 меншою давністю останніх реєстрацій (від 1-2 до 15-20 років) отримали категорії «зниклий» (напр., довгокрил та зубр), «вразливий» (Chionomys nivalis) або «рідкісний» (Sorex alpinus) ${ }^{2}$;

\footnotetext{
${ }^{1}$ Цей вид кажанів на більшій частині території України $є$ інвазивним, до того ж ще й виразним синантропом, який оселяється виключно у штучних спорудах (Zagorodniuk, Nehoda 2001).

2 Звісно, принаймні два останні види (снігурка альпійська і мідиця альпійська) є дотепер в регіоні, проте маємо визнати, що про них часом немає нових даних по два-три десятиліття.
} 
4) найбільшу нашу турботу мають викликати види, що отримали категорію «зникаючий». Таких видів у фауні Карпат шість; серед них чотири види кажанів, один гризунів та один хижих: підковик великий Rhinolophus ferrumequinum, нічниця триколірна Myotis emarginatus, нічниця ставкова Myotis dasycneme, широковух європейський Barbastella barbastellus (до того перший мав категорію «вразливий» і решта категорію «рідкісний»), снігурка альпійська Chionomys nivalis (раніше категорія «вразливий»), ведмідь бурий Ursus arctos (до того не був включений до ЧКУ). За особливостями ареалів 3 числа названих видів тільки останній (Ursus arctos) тісно пов'язаний з Карпатами, і така різка зміна категорії свідчить про те, що рівень загрози зникнення виду є надвисоким;

5) кілька видів, що мають стабільні (в Україні загалом) популяції, високу чисельність та широке поширення, в поточному (III) виданні ЧКУ визнано загроженими. Такими видами $\epsilon$ вечірниця руда Nyctalus noctula («вразливий»), пергач пізній Eptesicus serotinus («вразливий»), тхір лісовий Mustela putorius («неоцінений»). Не зрозумілі також мотиви включення до переліку рідкісних і зникаючих усіх без винятку видів нетопирів («неоцінені» і «вразливі»), включно 3 адвентивним Pipistrellus kuhlii та ймовірно адвентивним Pipistrellus pygmaeus (ix тут перенесено в список «незагрожених»: табл. 5);

6) особливу увагу викликають дані щодо видів-двійників, розрізнення яких у природних умовах становить певні складності, проте які віднесено в ЧКУ до різних категорій. Зокрема, у Червоній книзі України (2009) серед нових для цього видання видів опинилися три пари видівдвійників кажанів (Zagorodniuk 2018): три види 3 групи «вусатих» нічниць - Myotis brandtii («рідкісний»), M. mystacinus («вразливий») та M. alcathoe («вразливий»), два види «малих» нетопирів - Pipistrellus pipistrellus («вразливий») та P. pygmaeus («неоцінений»), два види вуханів - Plecotus auritus («вразливий») та P. austriacus («рідкісний»);

7) варто окремо відмітити складні місця у переліку категорій: частина видів не була оцінена (проте включена до III видання ЧКУ) через брак даних і тому отримала категорію «неоцінений» або «недостатньо відомий». Серед таких видів - «недостатньо відомий» [кому?] сліпак буковинський Spalax graecus (до цього мав категорію «рідкісний»), «неоцінені» [ким?] нетопир лісовий Pipistrellus nathusii (до цього не був у ЧКУ), тхір лісовий Mustela putorius (до цього не був в ЧКУ), видра річкова Lutra lutra (до цього була категорія «вразливий»). Очевидно, що різкі зміни цілого спектру категорій (від «без охорони» до «вразливий») на категорію «неоцінений» свідчать не так про брак даних щодо чисельності видів, як про недостатній аналіз наявних фактів та публікацій, а у стосунку до «мисливських» видів - ще й про ставлення авторів червоних переліків до державної статистичної звітності за формою «2ТП-мисливство» при формуванні цих переліків і «призначенні» категорій.

\section{Обговорення}

Оцінки категорій видів завжди були і залишаються складною задачею, яка вимагає докладного аналізу літератури, залучення даних фахівців та польового досвіду роботи експерта з визначення таких категорій. Не можна мати сумніву щодо кваліфікації авторів нових категорій. Проте не можна бути впевненим, що навіть докладний аналіз усіх доступних фактів дозволить зробити об'єктивну оцінку. Як приклад можна навести той факт, що за останні роки в окремих регіонах України виявлено колонії окремих видів кажанів, чисельність яких перевищує загальні оцінки в попередньому виданні ЧКУ для всієї України. Проте це зовсім не означає, що фактична чисельність таких видів (або окремих їхніх колоній) суттєво зросла. Зросла наша поінформованість, тобто збільшилися наші знання, а 3 ними й оцінки чисельності таких видів.

Проте, перед тим, як додатково до сказаного коментувати категорії видів, чисельність їхніх популяцій в Україні та зміни цих показників (табл. 3), варто сказати кілька слів про сам перелік видів ссавців, включених до ЧКУ. Як це прийнято у світовій практиці, такий перелік формується після оцінок стану популяцій кожного 3 наявних у фауні видів і створення певного рейтингу видів за рівнями їхньої вразливості чи раритетності. Аналіз «червоного» переліку 2009 року (на якому сформовано ЧКУ-4) засвідчує наявність суттєвих проблем і протиріч.

Насамперед, не зрозуміло, чому в Україні уникають використання загальноприйнятих у світі категорій видів, розроблених Міжнародним союзом охорони природи ще $2001 \mathrm{p}$. (IUCN ... 2001), тобто за рік до ухвалення Закону України про ЧКУ, і адаптованих до використання на регіональному рівні 2006 p. (IUCN ... 2006). Можна припустити, що такий крок вимагав би зміни багатьох категорій видів, а це вимагало би додаткової роботи, що розтягло би процес впорядкування українського «червоного» переліку. 
Таблиця 3. Повний перелік «червонокнижних» видів ссавців Карпат, внесених до попереднього (1994) та поточного (2009) видань «Червоної книги України» та формальна оцінка змін їх популяцій*

Table 3. Full list of Carpathian mammal species listed in the previous (1994) and current (2009) editions of the Red Data Book of Ukraine and a formal estimation of changes of their populations

\begin{tabular}{|c|c|c|c|c|}
\hline Ряд і вид & Категорія 1994 & Категорія 2009 & Оцінка змін & Поточна оцінка \\
\hline \multicolumn{5}{|l|}{ Insectivora - комахоїдні } \\
\hline Sorex alpinus & IV: невизначений & рідкісний & $>$ ? & VU \\
\hline Neomys anomalus & III: рідкісний & рідкісний & $=$ & VU \\
\hline \multicolumn{5}{|l|}{ Chiroptera - кажани } \\
\hline Rhinolophus hipposideros & II: вразливий & вразливий & $<$ & VU \\
\hline Rhinolophus ferrumequinum & II: вразливий & вразливий & $>$ & $\mathrm{EN}$ \\
\hline Miniopterus schreibersii** & II: вразливий & зниклий & $>>\uparrow$ & Ex \\
\hline Myotis blythii** & - & вразливий & $>$ & VU \\
\hline Myotis myotis & - & вразливий & $>$ & VU \\
\hline Myotis bechsteinii & III: рідкісний & вразливий & $=$ & VU \\
\hline Myotis nattereri & III: рідкісний & вразливий & $=$ & VU \\
\hline Myotis emarginatus & III: рідкісний & зникаючий & $>>$ & $\mathrm{EN}$ \\
\hline Myotis dasycneme & III: рідкісний & зникаючий & $>>$ & $\mathrm{EN}$ \\
\hline Myotis brandtii & - & рідкісний & $>$ & VU \\
\hline Myotis mystacinus & - & вразливий & $>$ & VU \\
\hline Myotis alcathoe & - & (у складі mystacinus) & $=$ ? & VU \\
\hline Myotis daubentonii & - & вразливий & $>$ & NT \\
\hline Plecotus auritus & - & вразливий & $=$ & NT \\
\hline Plecotus austriacus & - & рідкісний & $=$ & $\mathrm{LC}$ \\
\hline Barbastella barbastellus & III: рідкісний & зникаючий & $=$ & $\mathrm{EN}$ \\
\hline Nyctalus noctula & - & вразливий & $=$ & $\mathrm{LC}$ \\
\hline Nyctalus leisleri & III: рідкісний & рідкісний & $=$ & VU \\
\hline Pipistrellus pipistrellus & - & вразливий & $=$ & $\mathrm{LC}$ \\
\hline Pipistrellus pygmaeus & - & неоцінений & $=$ & $\mathrm{LC}$ \\
\hline Pipistrellus kuhlii (адвентивний!) & III: рідкісний & вразливий & $<<$ & $\mathrm{LC}$ \\
\hline Pipistrellus nathusii & - & неоцінений & $=$ & VU \\
\hline Vespertilio murinus & - & вразливий & $=$ & NT \\
\hline Eptesicus serotinus & - & вразливий & $=$ & $\mathrm{LC}$ \\
\hline Eptesicus nilssonii & - & рідкісний & $>$ & NT \\
\hline \multicolumn{5}{|l|}{ Rodentia - гризуни } \\
\hline Spalax graecus & III: рідкісний & недостатньо відомий & $>>$ & $\mathrm{CR}$ \\
\hline Eliomys quercinus & IV: невизначений & зникаючий & $>>>$ & Ex \\
\hline Sicista betulina & - & рідкісний & $>=$ & VU \\
\hline Arvicola scherman & III: рідкісний & - & $<<$ & $\mathrm{LC}$ \\
\hline Terricola tatricus & - & рідкісний & $>$ & VU \\
\hline Chionomys nivalis & III: рідкісний & вразливий & $=?$ & $\mathrm{EN}$ \\
\hline \multicolumn{5}{|l|}{ Carnivora - хижі } \\
\hline Ursus arctos & - & зникаючий & $>>$ & $\mathrm{EN}$ \\
\hline Mustela erminea & IV: невизначений & неоцінений & $=?$ & NT \\
\hline Mustela lutreola & II: вразливий & зникаючий & $>>>$ & $\mathrm{CR}$ \\
\hline Mustela putorius & - & неоцінений & $=$ & $\mathrm{LC}$ \\
\hline Meles meles & II: вразливий & - & $=$ & VU \\
\hline Lutra lutra & II: вразливий & неоцінений & $>$ & VU \\
\hline Felis silvestris $* *$ & I: зникаючий & вразливий & $<$ & NT \\
\hline Lynx lynx & II: вразливий & рідкісний & $>>$ & VU \\
\hline \multicolumn{5}{|l|}{ Artiodactyla — копитні } \\
\hline Bison bonasus & V: відновлений & зниклий в природі & $>>$ & $\mathrm{CR}$ \\
\hline
\end{tabular}

Примітка. * Усі записи в колонках «назви», «категорії» і «статус» наводяться за таблицею, вміщеною в Наказі № 313 Мінприроди, проте частину назв виправлено. ** Miniopterus schreibersii подано в ЧКУ так само, але в Наказі № 313 помилково як «M. scheibersii»; Myotis oxygnathus наведено в ЧКУ та Наказі 313 як «M. blythii», Felis silvestris подано в ЧКУ як «F. sylvestris», а в Наказі № 313 - двічі неправильно, як «Felix sylvestris». 
Мабуть, тому знову, як і в попередньому виданні ЧКУ (1994), з'явилися давно відхилені у всьому світі категорії для охорони, як «неоцінений» (напр., Mustela putorius) чи «недостатньо відомий» (напр., Spalax graecus), які взагалі не входять у обшар задач охорони тварин за класифікацією МСОП (за МСОП все це категоpiï з групи «not threatened», тобто «без загрози зникнення») (Zagorodniuk 2008b).

Тут (на прохання колег, які читали рукопис цієї статті) варто зробити одне зауваження: жодний 3 відомих нам авторів нарисів не був учасником жодного семінару або круглого столу з визначення категорій видів у новій редакції ЧКУ. І дискусія на спеціальному Круглому столі з питань охорони ссавців, який проходив восени 2009 р. у рамках роботи 16-ї Теріологічної школи-семінару, показала, що жодний $з$ учасників цього зібрання (а серед них були автори 37 (!) нарисів про ссавців до ЧКУ) не брав участь у обговоренні категорій і не мав таких запрошень, і кожний з присутніх на цій Школі авторів довідався про категорії видів вже після відповідного наказу Мінприроди (№ 313 від 17.06.2009) (Perelik ... 2009).

Тому для всіх колег залишається загадкою, чому широковух (Barbastella barbastellus) має статус «зникаючий», а рись (Lynx lynx) «рідкісний». Не зрозуміло, чому карпатські раритети так по-різному оцінено: мідиця альпійська (Sorex alpinus) і нориця татринська (Terricola tatricus) мають категорію «рідкісних», а снігурка альпійська (Chionomys nivalis) - «вразлива»? Виглядає так, що на сучасному рівні знань всі вони однаково рідкісні і вразливі. I чому ще один унікальний вид - сліпак буковинський (Spalax graecus), який добре відомий на Буковині і не менше тим колегам, які напевно мали би читати статті чернівецьких колег (напр.: Skilskyi et al. 2008; Tashchuk et al. 2009), оцінений як «недостатньо відомий»? Врешті, чому цей вид пройшов фільтр на включення до ЧКУ, а, наприклад, мідиця середня (Sorex caecutiens), відома в Україні за кількома знахідками (Gavrys et al. 2007; Dykyy, Srebrodolska 2008), не включена до «червоного» переліку?

Так само не зрозуміло, чому в III виданні ЧКУ раптом з'явився пергач пізній (Eptesicus serotinus) $)^{1}$, який мешкає чи не в кожному дворі по всій Україні, проте там відсутня рясоніжка

\footnotetext{
${ }^{1}$ Взагалі кількість видів кажанів у Червоній книзі вражає, і все це виглядає явним перекосом як у рівні уваги до різних груп тварин, так і у застосуванні критеріїв до визначення категорій раритетності.
}

водяна (Neomys fodiens), яку кожний фахівець 3 обліку мікромамалій ловить зазвичай не частіше одного разу на кілька років? Або чому в «червоному» переліку з'явився Equus caballus, тобто вид, відомий усім зоологам як «кінь свійський» (в ЧКУ назву перекладено як «кінь дикий»), ще й 3 категорією «зниклий у природі», i у той самий час дійсно зниклий в Українських Карпатах (ще на початку XX ст.) вид скельниця гірська, або козиця (Rupicapra rupicapra) не згаданий? I бабак гірський так само... У цьому стосунку $€$ цікавим той факт, що довгокрил європейський (Miniopterus schreibersii) визнаний вже зниклим (остання реєстрація в Україні 1990 року), а жолудниця європейська (Eliomys quercinus) - ще зникаючим видом (остання достовірна знахідка в Україні - 1976 року).

Кілька слів щодо проблем з категоріями «недостатньо відомий» та «неоцінний», згаданих в останньому 3 наведених вище пунктів (п. 7). Важливо зазначити, що часто рідкісність виду або відсутність публікацій про нього (а часом і просте незнання літератури) сприймають як «брак даних». Проте коли якийсь певний вид при нормальній інтенсивності досліджень реєструють лише раз на кілька років, це зовсім не означає, що маємо брак даних. Насправді ми маємо оцінку «дуже рідкісний, при стандартних обліках реєструється раз на кілька років». Чи дійсно горностай (Mustela erminea) такий «неоцінений» (так вказано в ЧКУ), чи все-таки він «рідкісний»? I чи такий само він «рідкісний» або «неоцінений», як тхір лісовий (в ЧКУ як «неоцінений»).

Так само відсутність або «рідкісність» даних про певний вид у оцінщика не може свідчити про потреби спеціальної охорони виду. У випадку, наприклад, з тхором лісовим (Mustela putorius) статистику щодо відвідування цим видом курників можна зібрати у кожному селищі. А щодо, скажімо, видри (Lutra lutra) отримати повноцінні дані можна у мисливствознавців, кожний $з$ яких скаже, що при всіх недоліках статистичної звітності «2ТП» можна сміливо покладатися не тільки на порядок цифр у ній, але й аналізувати багаторічні зміни чисельності (Rizun, Bondarenko 2016) та отримувати дані про чисельність виду в кожній з областей, чого не можна сказати про більшість інших груп (напр., кажанів або гризунів).

Питань щодо «червоного» переліку залишається багато. Проте одне 3 них - центральне: чи $є$ Червона книга керівництвом до природоохоронних дій? Відчуття підказують, що $\epsilon$, проте бажання вчиняти такі дії інколи пропадає. 
Зокрема, коли на довільно відкритій сторінці ЧКУ натрапляєш на рекомендацію щодо заходів охорони одного з найбільш звичайних видів кажанів (нетопир малий): «заборона господарських робіт у місцях поселення виводкових колоній 3 травня до вересня» (c. 508) ${ }^{1}$. Тобто у всіх лісах, зокрема й карпатських. Чи почули це лісники? Чи екологічної інспекція?

Пропозиції до IV видання ЧКУ. Очевидно, що видання наступного, четвертого тому Червоної книги України потребує ретельний підготовчий процес для коректного складання списку видів і вибору охоронних категорій, щоб уникати ті помилки та протиріччя, що були допущені при підготовці поточного видання. На жаль, за останні роки сформувалася чітка тенденція і доволі сумна перспектива виходу з-під контролю науковців нових даних щодо низки «червонокнижних» видів. Принаймні тих, обліки яких неможливо проводити дистанційними методами, а таких більшість.

Очевидно, що включення до ЧКУ кожного нового виду автоматично робить будь-які поточні його дослідження незаконними, аж до ризиків отримати покарання не тільки за його відлов при обліках фауни, але й за спробу взяти до колекції «рідкісний труп», якщо такий раптом буде знайдено. Мало матимемо мороки 3 трупом, ще й про протокол треба думати. Тому така інформація ставатиме дедалі менш доступною, і кожний новий крок до охорони виду закономірно вестиме до «зникнення» раритетів 3 результатів обліків фауни, які проводять як користувачі угідь, так і науковці.

Таким чином, існує потреба переглянути підходів до оцінки статусу виду та узгодження охоронних категорій, застосованих у ЧКУ, до прийнятих в усьому світі категорій МСОП.

Для найбільш повної оцінки статусу таксону необхідно аналізувати весь доступний масив даних, зокрема 3 метою виявлення закономірностей динаміки популяцій та обгрунтування необхідності охорони виду у разі негативної динаміки. Проте, оцінка динаміки популяцій у більшості випадків $є$ надто складною, а часом i неможливою задачею через брак даних, тому замість динаміки популяцій найчастіше аналізують динаміку ареалу. А картування ареалів

\footnotetext{
${ }^{1}$ Ще більш категоричною є рекомендація щодо режиму збереження нетопира Pipistrellus pygmaeus: «Заборона діяльності в місцях поселення виводкових колоній з травня до вересня». Особливо якщо врахувати, що всі достеменно відомі виводкові колонії цього виду в Україні пов'язані з будівлями.
}

найчастіше проводять методом мінімальних полігонів, що не відображає повною мірою особливості поширення виду (Burgman, Fox 2003).

При картуванні ареалів варто врахувати рекомендації МСОП і розрізнити такі їх складові як «область поширення/трапляння» (extent of occurence, EOO) та «область оселення» (area of occupancy, AOO) (IUCN..., 2001).

Область поширення $\epsilon$, по суті, тим же полігоном, який включає не тільки придатні для існування популяцій виду біотопи, але й непридатні, тобто включає області суцільного і переривчастого трапляння виду. Натомість, область оселення - це фактично зайнята видом площа в межах області поширення. Таким чином, скорочення області поширення не обов'язково означає скорочення області оселення, оскільки перше може означати скорочення "периферійних» популяцій, часом виступаючи просто як індикатор пульсації ареалу (що є природним процесом) при одночасному збільшенні області оселення в центрі ареалу.

Це особливо важливо для гірських видів, область поширення яких може бути на порядки ширшою за областю оселення, що пов'язано 3 високою гетерогенністю гірських ландшафтів (з великою часткою непридатних біотопів) та фактичним зменшенням загальної площі біотопів 3 висотою. Тому високогірні види завжди будуть рідкісними через обмежену площу придатних біотопів (область оселення) і мати відносно низьку чисельність через обмежену ємність середовища. Такі види вимагатимуть першочергової охорони, оскільки їх зникнення може кардинально змінити структуру екологічних взаємовідносин у високогірних угрупованнях.

Інша проблема - узгодження охоронних категорій, вжитих в українському законодавстві та нормативних документах із прийнятими у світі. Важливо розрізнити два поняття: «статус таксону» і «статус/категорія охорони».

Статус таксону не обов'язково $є$ одночасно і його охоронною категорією (табл. 4). Наприклад статус «неоцінений» не може бути охоронною категорією апріорі, оскільки вид не можна охороняти, якщо про нього нічого невідомо. Як такі види охороняти? Охорона виду це фактично заходи по збереженню його біотопу та екологічних зв'язків 3 іншими видами. Підхід «просто не чіпати, бо він у Червоній книзі» - не є охороною; навпаки, внесення виду до ЧКУ обмежує його подальші дослідження i встановлення реального охоронного статусу (власне статусу, а лише потім, при необхідності, категорію його охорони). 
Таблиця 4. Статуси і охоронні категорії видів за МСОП, пропоновані для застосування у ЧКУ

Table 4. Statuses and conservation categories of species according to IUCN proposed to be used in RDBU

\begin{tabular}{llll}
\hline Позначення рівня уваги до виду & \multicolumn{1}{c|}{ Англійська назва } & \multicolumn{1}{c}{ Українська назва } \\
\hline Статус & & Data deficient (DD) & Неоцінений \\
Статус & Категорія охорони & Least concern (LC) & Не загрожений \\
Статус & Категорія охорони & Vulnerable $(V U)$ & Рідкісний \\
Статус & Категорія охорони & Endangered $(E N)$ & Вразливий \\
Статус & Категорія охорони & Critically endangered $(C R)$ & Зникаючий \\
Статус & Категорія охорони & Extinct in the wild $(E W)$ & Бникикий до зникнення \\
Статус & & Extinct (Ex) & Зниклий \\
Статус & & & \\
\hline
\end{tabular}

Таблиця 5. Повний перелік ссавців карпатського регіону, які включалися до одного з червоних списків або рекомендуються до них, та пропоновані до IV видання ЧКУ статуси за класифікацією МСОП

Table 5. Full list of Carpathian mammals, which were included into one of the red lists or recommended to such lists, and their proposed conservation statuses according to IUCN to the IV edition of the RDBU

\begin{tabular}{|c|c|}
\hline $\begin{array}{l}\text { Статус та категорія } \\
\text { охорони }(*)\end{array}$ & Таксони \\
\hline Неоцінений (DD) & - \\
\hline Не загрожений (LC) & $\begin{array}{l}\text { Chiroptera — Plecotus austriacus, Nyctalus noctula, Pipistrellus pipistrellus, Pipi- } \\
\text { strellus pygmaeus, Pipistrellus kuhlii (адвентивний), Eptesicus serotinus } \\
\text { Rodentia - Arvicola scherman } \\
\text { Carnivora - Mustela putorius }\end{array}$ \\
\hline Рідкісний (NT)* & $\begin{array}{l}\text { Chiroptera - Myotis daubentonii, Plecotus auritus, Eptesicus nilssonii, Vespertilio } \\
\text { murinus } \\
\text { Carnivora — Mustela erminea, Felis silvestris }\end{array}$ \\
\hline Вразливий (VU)* & $\begin{array}{l}\text { Insectivora - Sorex alpinus, Neomys anomalus; Chiroptera - Rhinolophus hippo- } \\
\text { sideros, Myotis blythii, Myotis myotis, Myotis bechsteinii, Myotis nattereri, Myotis } \\
\text { brandtii, Myotis mystacinus, Myotis alcathoe, Nyctalus leisleri, Pipistrellus nathusii } \\
\text { Rodentia (гризуни) - Sicista betulina, Terricola tatricus } \\
\text { Carnivora - Meles meles, Lutra lutra, Lynx lynx }\end{array}$ \\
\hline Зникаючий (EN)* & $\begin{array}{l}\text { Chiroptera - Rhinolophus ferrumequinum, Myotis emarginatus, Myotis dasycneme, } \\
\text { Barbastella barbastellus } \\
\text { Rodentia - Chionomys nivalis } \\
\text { Carnivora - Ursus arctos }\end{array}$ \\
\hline $\begin{array}{l}\text { Близький до зникнення } \\
(\mathrm{CR})^{*}\end{array}$ & $\begin{array}{l}\text { Rodentia - Spalax graecus, Mustela lutreola } \\
\text { Artiodactyla - Bison bonasus }\end{array}$ \\
\hline Зниклий у природі (EW)* & - \\
\hline Зниклий (Ex) & $\begin{array}{l}\text { Chiroptera - Miniopterus schreibersii } \\
\text { Rodentia - Eliomys quercinus }\end{array}$ \\
\hline
\end{tabular}

Тому, з огляду на все вищенаведене, статуси і категорії карпатських ссавців необхідно переглянути, що і зроблено авторами. Такі дані узагальнено в таблиці 5.

\section{Післямова}

Ссавці - невипадково одна 3 найуразливіших груп тварин (Zagorodniuk 1997). Люди здобувають їх і руйнують їхнє середовище, а почасти категорично не бажають мати такого сусідства, i цей стос проблем веде до невпинного згасання популяцій багатьох колись звичайних видів.

Це все ознаки прогресу у розвитку людської цивілізації. Берегти у нас звикли тільки рідкісне, а не те, що згасає. От коли згасне.... Тоді й проявимо турботу. Якщо встигнемо. Проте чи збільшується наша цивілізованість 3 кожним знищеним видом? Чи цінність якогось 
виду, у тому числі його абсолютна цінність для нашого спільного з ним середовища визначається виключно статусом його рідкісності? Чи може не рідкісний вид бути цінним (хоча б для нас, проте не як консументів, а як мешканців певного сегменту біосфери 3 назвою «Україна») і заслуговувати на нашу охорону? Врешті, чи $\epsilon$ Червона книга лише довідником про майже втрачене різноманіття, чи вона має якось допомогти дикій фауні? Або нам.

Сподіватимемося, хоч чимось допоможе... Наприклад, допоможе змінити наше ставлення до дикої природи, визнати потреби охорони насправді рідкісних (через нас) і насправді вразливих (до наших впливів) звірів. Кажанів і землерийок, гризунів і хижаків. Може, тоді і зубр залишиться в Карпатах, а не буде рахуватися заживо похованим, з новим позірним статусом «зниклий у природі» замість колишнього «відновлений» ${ }^{1}$.

Чи може, спочатку вирішимо, що ми маємо охороняти в першу чергу, а потім і те, як ми будемо (хочемо?, можемо?, мусимо?) це робити? Інакше, нова Червона книга не допоможе жодному виду. Як не допомогли іiі попередні видання. Бо говорити, що ЧКУ допомогла аж двом видам ссавців - борсуку і повху - буде неправдою. Вони збереглися і не погіршили стан своїх популяцій аж ніяк незалежно від Червоної книги та охоронного статусу, попри те, що обох їх нещадно нищили і продовжують нищити. Просто була помилка у тому, що вони були включені до Червоної книги.

Наразі з'ясовувати причини усіх названих і неназваних «проколів» не має сенсу. I шукати винних у тому, що ставлення до ЧКУ і загалом ідей охорони біотичного різноманіття буде формуватися після знайомства 3 цим виданням більше, ніж після читання спеціальних публікацій. Здається, головна проблема полягає у тому, що невідповідальне ставлення фахівців породжує таке ж ставлення пересічних громадян до потреб охорони фауни і теми Червоної книги. А почалося все $з$ незацікавленості самої держави, а не Комісії, у вирішенні цих проблем і невиправданої гарячки 3 підготовкою ЧКУ, викликаної позицією «зелених»: вони намагалися виконати свою місію, проте вийшло все як завжди. Не спрацювала вся система. Хоча всі разом і кожний окремо доклали чималих зусиль.

\footnotetext{
${ }^{1}$ Певного заспокоєння додає те, що в тексті нарису про зубра вказано дослівно наступне: «Зараз зубр зберігся скрізь, крім Чернігівської обл.». Проте це не варто сприймати буквально.
}

Але навіщо нам чи фауні такі надриви? Пройшли чергові 10 років, і прийшов час підготовки нового видання ЧКУ. Чи будуть гонки і чи залучать до роботи тих, хто мав би бути експертами? Час покаже. Досягти більшої результативності, ніж це сталося при підготовці ЧКУ 2009 р., можна, використовуючи наявний міжнародний досвід. Найперспективнішою виглядає практика МСОП, яка полягає у формуванні тематичних робочих груп та їхній роботі з поновлення даних про стан кожного з видів, із подальшим викладенням актуальної та постійно поновлюваної інформації у вільному доступі (https://www.iucnredlist.org) (Zagorodniuk 2008b).

Таке роблять без термінової підготовки наказів Мінприроди, які потім складно змінювати, без традиційного поділу авторства і без авральної здачі до друку чергового тому з подальшим забуттям цієї теми на нові 10 років і навіть без перевидання з виправленими помилками. Ідея видання у МСОП залишилася у XX ст., як й сама ідея власне «червоних списків», бо оцінювати треба не довільно взятий (впорядкований чиновником) список видів, а по можливості всі види, які $є$ об'єктами уваги. І лише потім обираючи з бази даних для розробки й реалізації Планів дій ті з видів, які потрапляють у групу «третових» (threatened species, іншими словами «загрожені види»), тобто мають одну 3 трьох високих категорій - VU або EN або CR.

Тоді не виникатиме питань щодо включення чи невключення певних видів у «червоні» списки, немає амбіцій щодо авторства і немає проблем із поновленням таксономічних або популяційних даних, мап, джерел, а хоч би й наукових і вернакулярних назв. Годі казати про те, що статуси видів можуть доволі швидко змінюватися внаслідок глобальних кліматичних змін, впливів стихій, антропогенних факторів та чужорідних видів.

\section{Подяки}

Дякуємо всім учасникам 16-ї та подальших Теріологічних шкіл-семінарів за важливі дискусії 3 питань охорони теріофауни на традиційному круглому столі «Ссавці у Червоній книзі України», а надто С. Гащаку, М. Дребету, А. Дулицькому, I. Євстаф'єву, Г. Зайцевій, С. Жилі, В. Лобкову, А. Каштальяну, В. Миропольському, М. Роженку, 3. Селюніній, Є. Скоробогатову, В. Тищенку, М. Товпинцю, П. Хоєцькому. Дякуємо Д. Вишневському, О. Годлевській, П. Гольдіну, В. Придатку за важливі зауваження щодо проекту статті. Дякуємо секретарю видання В. Мірутенку за роботу з рукописом. 
BARKASZI Z. (2016) Endemism in the mammalian fauna of the Carpathians. Proceedings of the Theriological School, 14, 3-15. http://doi.org/10.15407/ptt2016.14.003

BARKASZI Z. (2018) Changes in the rodent fauna (Mammalia, Glires) of the region of the Ukrainian Carpathians during the XIX-XXI centuries. Geo\&Bio, 16, 48-62. doi: https://doi.org/10.15407/gb.2018.16.048

BURGMAN M. A., FOX J. C. (2003) Bias in species range estimates from minimum convex polygons: implications for conservation and options for improved planning. Animal Conservation, 6, 19-28. https://doi.org/10.1017/S1367943003003044

CHERVONA knyha Ukrainskoi RSR [Red Data Book of the Ukrainian SSR] (1980). Naukova Dumka, Kyiv, 1-504 (in Ukrainian).

CHERVONA knyha Ukrainy, Tvarynnyi svit [Red Data Book of Ukraine. Animals] (1994). Ukrainska Encyklopedia, Kyiv, 1-464 (in Ukrainian).

CHERVONA knyha Ukrainy, Tvarynnyi svit [Red Data Book of Ukraine. Animals] (2009) Ed. by Akimov I. A. Globalkonsalting, Kyiv, 1-624 (in Ukrainian).

CHIŞAMERA G., BUŽAN E. V., SAHLEN T., MURARIU D., ZUPAN S., KRYŠTUFEK B. (2014) Bukovina blind mole rat Spalax graecus revisited: phylogenetics, morphology, taxonomy, habitat associations and conservation. Mammal review, 44, 1929. https://doi.org/10.1111/mam.12001

DYKYY I., ZAGORODNIUK I. (2005) Vovchok sadovyi (Eliomys quercinus) iz Zakarpattia u fondakh Zoolohichnoho muzeiu imeni Benedykta Dybovskoho (Lviv) [The garden dormouse (Eliomys quercinus) from Zakarpattia in the stock collection of Benedikt Dybowski Zoological Museum (Lviv)]. Vestnik zoologii, 39(3), 84 (in Ukrainian).

DYKYY I., SREBRODOLSKA YE. (2008) Ridkisni i malochyselni vydy ssavtsiv Shatskoho natsionalnoho pryrodnoho parku [Rare and non-abundant mammalian species of the Shatsky National nature park]. In: Zagorodniuk I. (ed.) Rarytetna teriofauna ta ii okhorona [Fauna of Rare Mammals and its Protection]. Luhansk, 102-106.

GAVRYS G. G., KUZMENKO YU. V., MISHTA A. V., KOTSERZHYNSKA I. M. (2007) Fauna khrebetnykh tvaryn Natsionalnoho pryrodnoho parku "Desniansko-Starohutskyi" [Vertebrate Fauna of Desniansko-Starohutskyi National Nature Park]. Kyiv, 83 (in Ukrainian).

IUCN Guidelines for the Application of Red List Criteria at Regional levels (2006). Accessed from www.iucn.org/themes/ssc/redlists/regionalguidelines. htm

IUCN Red List Categories and Criteria: Version 3.1 (2001) IUCN Species Survival Commission Gland, Cambridge, 1-30. Accessed from http://www.iucnredlist.org/info/categories_criteria.ht $\mathrm{ml}$

KOLYUSHEV I. I. (1957) O vertikalnom raspredelenii mlekopitayushchikh Zakarpattia [On the altitudinal distribution of mammals of Zakarpattia]. Doklady $i$ soobshcheniya. Seriya biologiya, 1, 29-30 (in Russian).

KOROBCHENKO M., ZAGORODNIUK I. (2009) Taksonomiia ta rivni dyferentsiatsii slipakiv (Spalacidae) fauny Ukrainy i sumizhnykh krain [Taxonomy and levels of differentiation in mole-rats (Spalacidae) of the fauna of Ukraine and adjacent countries]. Scientific Bulletin of Uzhgorod University (Series Biology), 26, 13-16 (in Ukrainian).

KYSELIUK O. I. (1993) Osoblyvosti vertykalnoho poshyrennia dribnykh ssavtsiv Ukrainskikh Karpat [Features of altitudinal distribution of small mammals in the Ukrainian Carpathians]. In: Fauna Skhidnykh Karpat: suchasnyi stan $i$ okhorona [Fauna of the Eastern Carpathians: Current State and Protection]. Uzhhorod, 68-70 (in Ukrainian).

MATELESHKO O. YU., POTISH L. A. (eds.) (2011) Chervona Knyha Ukrainskykh Karpat. Tvarynnyi svit [Red Data Book of the Ukrainian Carpathians. Animals]. Uzhhorod, 1-331 (in Ukrainian).

PARKHOMENKO V., ZAGORODNIUK I. (2012) XVI Teriolohichna shkola-seminar «Dynamika populyatsiy ta khyzhatstvo» (Poliskyy zapovidnyk, 2009) [Teriological school-seminar "Dynamics of populations and predation" (Polissian Nature Reserve, 2009)]. Proceedings of the Theriological School, 11, 148-153 (in Ukrainian).

PARNIKOZA I. YU., GODLEVSKA O. V., SHEVCHENKO M. S., INOZEMTSEVA D. N. (2005) Fauna Ukrainy: okhrannye kategorii (spravochnik) [Fauna of Ukraine: Conservation Categories (handbook)]. Zagorodniuk I. (Ed.). Ecological and cultural centre of Kyiv, Kyiv, 1-60 (in Russian).

PERELIK vydiv tvaryn, yaki vkliucheni do III vydannia Chervonoi knyhy Ukrainy [List of Animal Species Included into the Third Edition of the Red Data Book of Ukraine]. Kyiv, 2009.

POKYNCHEREDA V. F. (1991). Novye nakhodki dlinnokryla obyknovennoho v Vostochnykh Karpatakh [New records of Schreibers's long-fingered bat in the Eastern Carpathians]. Vestnik zoologii, 3, 59 (in Russian).

RIZUN E., BONDARENKO V. (2016) Dynamichni tendentsiyi stanu populyatsiy myslyvs'koyi teriofauny Ukrayiny ta propozytsiyi shchodo vdoskonalennya oblikovykh robit [Trends in population dynamics of the Ukrainian game mammal fauna and propositions on improvement of its census]. Proceedings of the Theriological School, 14, 34-40 (in Ukrainian). http://doi.org/10.15407/ptt2016.14.034

SACHANOWICZ K., WOWER A., BASHTA A.-T. (2006) Further range extension of Pipistrellus kuhlii 
(Kuhl, 1817) in central and eastern Europe. Acta Chiropterologica, 8(2), 543-548.

SKILSKYY I. V., MELESHCHUK L. I., TASHCHUK M. V. (2008) Ssavtsi pivdenno-skhidnoi chastyny Bukovynskoho Peredkarpattia [Mammals of the southeast part of Bukovinian Peredkarpattia]. In: Zatulovska O. P., Piddubnyi I. A., Skilskyi I. V. (eds.) Suchasnyi muzei. Naukova i ekspozytsiina diyalnist [Modern Museum. Scientific and Displaying Activity]. Chernivtsi, 52-67 (in Ukrainian).

SOKUR I. T. (1951) Do pytannia pro zooheohraphichnu kharakterystyku Radianskykh Karpat [To the issue of zoogeographic description of the Soviet Carpathians]. Dopovidi AS UkrSSR, 3, 198-201 (in Ukrainian).

STETSULA N. O. (2015) Pryrodookhoronnyy status rarytetnykh ssavtsiv Peredkarpattia [Protected status of rare mammals in Precarpathians]. Scientific Issues Ternopil Volodymyr Hnatiuk National Pedagogical University. Series Biology, 1, 137-144. (in Ukrainian).

TASHCHUK M. V., SKILSKYY I. V., MELESHCHUK L. I. (2009) Bukovinskiy slepysh V Vostochnom Predkarpatye: sovremennoye sostoyanie populiatsiy [Bukovina blind mole rat in the Eastern Precarpathians: current state of populations]. In: Suchasni problem biolohii, ekolohii ta khimii: zbirka materialiv II Mizhnarodnoi konferentsii [Current Problems of Biology, Ecology and Chemistry: Book of Abstracts of the $2^{\text {nd }}$ International Conference]. Zaporizhzhia, 77-79.

TATARINOV K. A. (1955) Do pytannia pro vertykalne poshyrennia ssavtsiv u Skhidnykh Karpatakh [To the issue of altitudinal distribution of mammals in the Eastern Carpathians]. Naukovi zapysky Pryrodoznavchoho тиzеiu AS UkrSSR, 4, 80-91 (in Ukrainian).

WILSON D. E., REEDER D. M. (eds.) (2005) The Checklist of Mammal Names (according to: Mammal Species of the World. Johns Hopkins University Press. Accessed from http://www.bucknell.edu/msw3/.

WITKOWSKI Z. J., KRÓL W., SOLARZ W. (eds.) (2003) Carpathian list of endangered species. WWF and Institute of Nature Conservation, Polish Academy of Sciences, Vienna, Krakow, 1-84.

ZAGORODNIUK I. V. (2000) Systematychne polozhennia taksona yak kryterii yoho vrazlyvosti [Systematic position of the taxon as criterion of its vulnerability]. Reports of NAS of Ukraine, 5, 180-186 (in Ukrainian).

ZAGORODNIUK I. (2008a) Rarytetna fauna ta oznaky rarytetnosti [Rare fauna and signs of rarity]. In: Zagorodniuk I. (ed.) Rarytetna teriofauna ta ii okhorona [Fauna of Rare Mammals and Its Protection]. Luhansk, 7-20 (in Ukrainian).

ZAGORODNIUK I. (2008b) Otsinyuvannya yevropeys'kykh ssavtsiv: pidsumky roboty komisiyi MSOP [European Mammal Assessment: totals of IUCN workshop]. Rarity mammal fauna and its protection (Series: Proceedings of the Theriological School, 9). Zagorodniuk, I. (Ed.). Luhansk, 283-287. (in Ukrainian).

ZAGORODNIUK I. (2014) Changes in taxonomic diversity of Ukrainian mammals for the last three centuries: extinct, phantom, and alien species. Proceedings of the Theriological School, 12, 3-16.

ZAGORODNIUK I. (2018) Blyz'ki vydy kazhaniv u fauni Ukrayiny: vidminnosti ta mistse $\mathrm{v}$ strukturi uhrupovan' [Close bat species in the Ukrainian fauna: differences and position in the structure of communities]. Theriologia Ukrainica, 16, 51-76 (in Ukrainian). http://doi.org/10.15407/pts2018.16.003

ZAGORODNIUK I., POKYNCHEREDA V., KYSELIUK O., DOVHANYCH YA. (1997) Teriofauna Karpatskoho biosfernoho zapovidnyka [Mammal fauna of the Carpathian Biosphere Reserve]. Institute of Zoology of NAS of Ukraine, Kyiv, 16-23. (Supplement 5 to Vestnik zoologii) (in Ukrainian).

ZAGORODNIUK I., NEHODA V. (2001) Netopyry: Pipistrellus ta Hypsugo [Pipistrelle bats: Pipistrellus and Hypsugo]. In: Mihratsiinyi status kazhaniv $v$ Ukraini [Migration Status of Bats in Ukraine]. Kyiv, 65-72 (in Ukrainian).

ZAKON Ukrainy "Pro Chervony knyhu Ukrainy" [Law of Ukraine "On the Red Data Book of Ukraine"]. Kyiv, 2002. No. 3055-III (07.02.2002) (in Ukrainian). 